employment for villagers in the protected areas, as guides and jeep drivers, for example. Both Gorumara and Jaldapara also hire many local people part-time. The villagers assist when needed, including in anti-poaching, fire control and providing information on potential poachers.

The villagers understand that if the forest and its animals are well protected they will receive greater benefits from the Forest Department. 'If the people protect the jungle and its animals, they can be sustained by it', explained a Range Officer in Gorumara who gives the villagers regular talks about the benefits of conserving rhinos and the forest. He acknowledged that having thousands of pairs of eyes around Gorumara and Jaldapara provides the best wall of protection. Although the region is close to the porous borders with Nepal, Bhutan and China, foreign poachers are rarely able to penetrate this barrier of local people. The villagers are a close-nit community who want to protect their rhinos. The forest staff have carried out awareness campaigns on rhino conservation, and effective management in the Forest Department has boosted staff morale and motivation. Mobile phones have strengthened the information gathering process (cf. Oryx, 46, 137-144), helping to prevent poaching more effectively. The Department's activities are transparent, whereby anyone, including forest guards, can contact senior staff to report corruption, and the media is active in reporting misdemeanours. Officials follow up on such reports. Penalties for illegal killing of wildlife and trading in wildlife products are sufficient and often implemented.

Despite the high export price for rhino horn of c. USD $13,000 \mathrm{~kg}^{-1}$, rhino poaching is now under control in West Bengal because of ever-improving vigilance. It is a success story from which other rhino range states can learn that the concept 'man management is the best management for protected areas' actually works, by winning the confidence and trust not only of the staff but also of the local people.

LuCy Vigne and Esmond Martin PO Box 15510, Nairobi 00503, Kenya

E-mailrhino@wananchi.com

\section{Conservation Leadership Programme announces 2012 awards}

The Conservation Leadership Programme (CLP) supports exceptionally talented, early-career conservationists who are striving to safeguard threatened species and habitats worldwide. In April the CLP announced the winners of its annual awards and granted c. USD 490,500 to 28 projects in 22 countries. Of these, 24 are new projects, two are Followup projects and two are Conservation Leadership Awards that provide substantial resources to first-rate innovative and original projects previously supported by the
Programme. This year the newly funded projects range from classic research projects (e.g. Population trends of marmosets in the Brazilian Amazon) to youth work aimed at improving attitudes towards Amur tigers in Russia, and capacity building among coastal fishing groups in Kenya. The two top awards, each worth USD 50,000, were won by a Cuban project to promote the conservation of the island's plant life, and a Colombian project to protect important habitat for the Critically Endangered Niceforo's wren and Endangered chestnut-bellied hummingbird. To view a full list of funded projects visit http://www.conservationleadershipprogramme.org/projects.asp. A representative from each award-winning team recently took part in CLP's Conservation Management \& Leadership Training Workshop at a remote ecological research station in the foothills of the Canadian Rockies. The workshop covered topics such as project planning, behaviour change through education and outreach, media training, climate change and fund-raising. Beyond the project funding and training, each award-winning team member will join a network of over 3,500 CLP alumni. This network helps awardees implement conservation projects and carry out research in often challenging and isolated environments. Alumni members also receive access to additional grants, specialized training courses and mentoring from CLP staff and conservation experts. The Programme was initiated in 1985 and is a partnership between Fauna \& Flora International, BirdLife International, Conservation International and the Wildlife Conservation Society. See p. 466 for the call for applications for the 2013 awards.

Stuart Paterson Conservation Leadership Programme, Fauna \& Flora International, Cambridge, UK

E-mail stuart.paterson@fauna-flora.org

\section{9th annual Whitley Awards}

The 19th annual Whitley Awards Ceremony was held on 9 May 2012 at the Royal Geographical Society in London. The flagship event of UK-based charity the Whitley Fund for Nature was hosted by writer and broadcaster John McCarthy, and saw seven conservation leaders from seven different countries receive Whitley Awards worth GBP 30,000 each in project funding over 1 year in support of their work. In addition, a special Whitley Gold Award was presented to 2004 Whitley Award winner Rodrigo Medellin of Mexico for his outstanding contribution to the conservation of bats in Latin America with the help of Continuation Funding from WFN. Over 400 people attended the event, where the charity's patron, HRH The Princess Royal, presented the Awards. The 2012 Whitley Award Winners are: Joanna Alfaro Shigueto, Peru (Conservation of threatened marine fauna through sustainable coastal fisheries); Inza Koné, Ivory Coast 
(Community-led conservation of Critically Endangered West African primates); Carlos Vasquez Almazan, Guatemala (Guatemala's first network of protected areas for amphibian conservation); Budiono, Indonesia (Protection of Indonesia's last population of freshwater dolphins); Josia Razafindramanana, Madagascar (Metapopulation management of Endangered crowned sifaka); Bernal Rodriguez Herrera, Costa Rica (Cross-border capacity building for conservation of Central American bats); Lisel
Alamilla, Belize (Uniting stakeholders for the conservation of the Maya Golden Landscape). For more information on the Whitley Fund for Nature, the Whitley Awards and to view short films about each of the winning projects, see http://www.whitleyaward.org/. See p. 466 for the call for applications for the 2013 awards.

DAVID WALLIS Whitley Fund for Nature, London, UK

E-maildavid@whitleyaward.org 